\title{
Varying concepts of planning and control in dependency upon characteristic features of logistics, branches and IT-support
}

\author{
P. Schönsleben \\ Institute of Industrial Engineering and Management BWI \\ Swiss Federal Institute of Technology ETH Zurich \\ Zurichbergstrasse 18, CH 8028 Zurich, Switzerland \\ Fax: +4116321040 \\ e-mailsch@bwi.bepr.ethz.ch
}

\begin{abstract}
The introduction and implementation of logistics software is often judged costly, tediously time-consuming, inflexible and restrictive with regard to business processes. This kind of reproach refers to all kinds of ERP-type software: shop floor scheduling systems, larger legacy systems like PPC-software, or the recent SCM software. Furthermore, different people in an enterprise tend to different views on the goodness of varying approaches to and concepts of planning and control in logistics. This has led, and continues to lead, to highly charged debates. Through argumentation that is often polemic, one concept is played off against the other. Rarely, the different businesses in an enterprise are recognized as different in their characteristic features of logistics.

In an effort to contribute to more objective discussion, this paper shows that four classes of concepts on planning and control have become established over recent decades: the MRPII (ERP) concept, the Just-in-Time/Kanban concepts, variantoriented concepts, and process-oriented concepts. These varying concepts are then examined in dependency upon characteristic features of planning and control and in dependency upon branch of industry. The paper shows that, as a consequence in practice, several concepts of planning and control may and have to be applied in an enterprise. The recent changes in the APICS' body of knowledge and certification curriculas reflect the varying concepts. The paper shows also the different kind of software linked with these different concepts and mentions some actual and future developments.
\end{abstract}


Keywords

Production Planning and Control, MRPII, Just in Time, One-of-a-kind Production, Process Industry.

\section{VARYING CONCEPTS OF PLANNING AND CONTROL IN DEPENDENCY UPON THE LAST DECADES}

Recent decades saw the development of different concepts of planning and control in logistics networks. Each was developed in a particular area and so represents to a certain degree a model for a branch of industry. Some of the concepts arose in powerful industries, such as the automobile or machine industry. The concepts were systematized and given brand names.

- The MRPII concept (manufacturing resource planning. should not be confused with the MRP method of materials requirement planning.) originated in North America in the late 1960's. The three temporal ranges of planning and control (short, medium and long range) were basic to the MRPII concept that quite early on went beyond matters of production. MRPII was developed in branches of industry having clearly convergent product structures, such as for the construction of big machines and in the automobile and aircraft industries. Further development of the concept led to the ERP, enterprise resource planning concept in order to include all areas of a company.

- In the late 1970's, Japan introduced the just-in-time concept aimed at improving the flow of goods. Marketed initially as a contrasting alternative to the MRPII concept, the just-in-time concept has turned out to be also generally valid and fundamental to planning and control in ERP when delivery becomes a targeted company priority. The Kanban system, often linked with a goods flow orientation, however, is applicable only to production or procurement involving frequent repetition. Flow of goods concepts, as well as simple methods of resource management, form an important extension to the MRPII concept and its methods.

The details of resource management developed by ERP remain fundamentally valid in the extended concepts below. These extensions differ from the classic ERP concept mainly, particularly in the modeling of logistics objects and, accordingly, in order processing and order coordination in all temporal ranges of planning. The tasks are then based on correspondingly extended logistics business objects:

- Various variant-oriented concepts originated in Europe in the late 1970's. They were developed in connection with the product concept of product family and 'one of a kind', nonrepetitive production. They are necessary extensions of previous concepts. Depending on the product concept, different types of order management can be derived, namely

- Individual or standard products with variants (repetitive production, possibly with stockkeeping; small series are possible) 
- Product families (production of variants with infrequent repetition, single unit production according to the customer order)

- Product families with multiple variants (single unit production, in tendency 'one of a kind' production)

- Production according to (changing) customer specification ('one of a kind' production).

- In the late 1980's, process oriented concepts were developed in North America for process industries. These concepts extend the MRPII concept, but did not yet find a complete systematization. They link to the concept called process flow scheduling. They consider divergent product structures, a phenomenon not covered adequately by earlier concepts. Mass production, concepts of campaigns (due to high setup cost), continuous flow production and cycles in the production structure are typical features for process industries. The classical concepts for master data and order data management have to be extended. Goods and capacities are resources of same importance. Process orientation dominates.

For more details, see (Schönsleben 1998, Wight 1981 and Vollmann et al. 1998).

\section{VARYING CONCEPTS OF PLANNING AND CONTROL IN DEPENDENCY UPON CHARACTERISTIC FEATURES}

Figure 1 summarizes the varying concepts and shows their dependency on the following characteristic features of planning and control in logistics networks, namely the Orientation of product structure and the Frequency of production or procurement order repetition.

The colored areas indicate the areas of application of the underlying MRPII concept and extended concepts. Orientation of product structure and frequency of production or procurement order repetition thus prove to be the most important features with regard to the pragmatic development of concepts for planning and control in logistics.

It is of no consequence to business methods, by the way, whether planning and control are performed manually or with computer support. In a similar way, it does not matter whether the computer-aided system is a shop floor scheduling system or a larger legacy system, f.ex. a legacy system. The methods remain the same. What varies are form and flexibility of presentation and user comfort. 


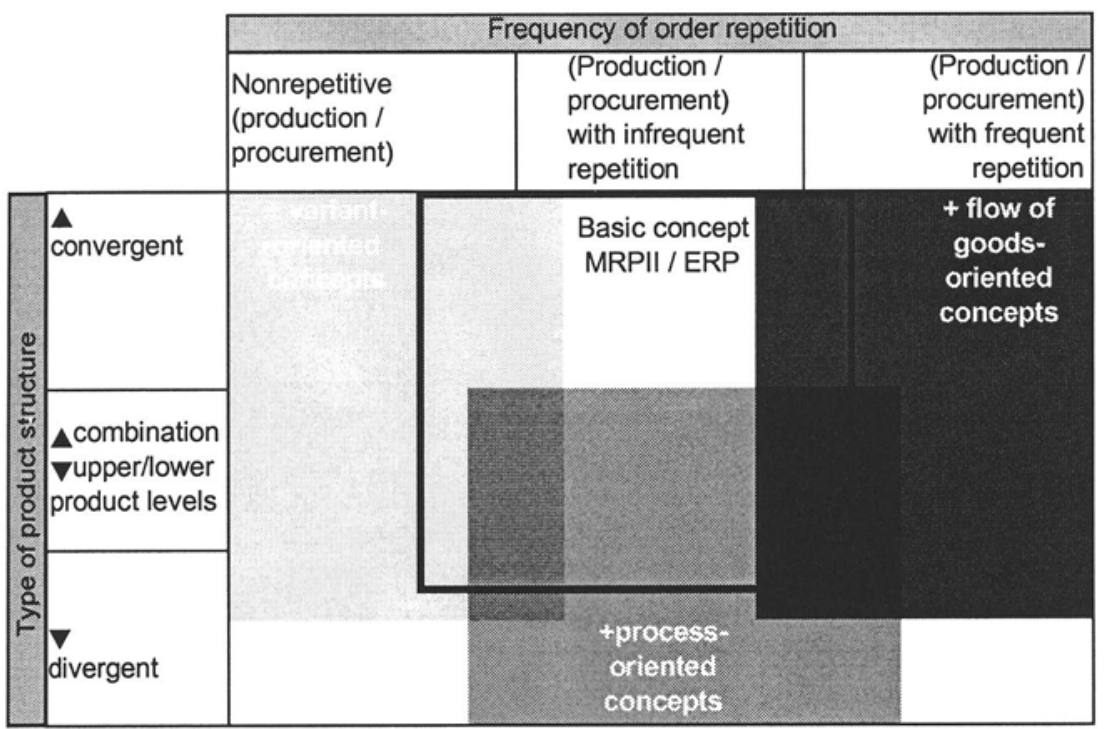

Figure 1 Varying concepts of planning and control in dependency upon the characteristic features orientation of product structure and frequency of production or procurement order repetition.

Interestingly, the main streams of software packages follows the framework in Figure 1. Examples of MRPII/ERP-Software are Copics and Mapics, Cincom, TPS (Burroughs), Manufacturing (Oracle), Bpics, J.D.Edwards SAP R/3. Typical flow of goods concepts and methods like Kanban need no IT-support. Examples of software supporting various variant-oriented concepts are Baan, Piuss (PSI), MAS90, Diaprod (Seitz), Miracle (Lynx), and many other niche products for branches, as furniture or windows. Examples for software for process oriented concepts Prism / Protean (Marcam), Cimpro (Datalogix), Promix (Ross Systems), Process One (Arthur Andersen) und MFG-PRO (QAD).

On the global scene, the 1990's have seen further expansion of these concepts into trans-corporate planning and control. These concepts are called supply chain management (SCM) or advanced planning and scheduling (APS). A new generation of Software to support production and logistics networks is today on the market, f.ex. Numetrix, Rhythm (i2-Technologies), SynQuest, Manugistics, SAP/APO. Interestingly, some evolved from Leitstand-Software, some are extensions to ERP-software, constructed around software kernels, such as ILOG.

Implementation of SCM concepts is in progress, but the newer extended ideas have not yet led to the formulation of explicit concepts such as those above. We can expect to see further development of concepts of transcorporate planning and control in the near future. 


\section{VARYING CONCEPTS OF PLANNING AND CONTROL IN DEPENDENCY UPON BRANCH OF INDUSTRY (BRANCH MODELS)}

A branch of industry is the area of business a company belongs to. The various branches of industry and areas of business are defined, f.ex., in governmental statistics on economics and industry. Typical industrial branches are the chemical industry, plastic industry, the electronics and electrical industries, the aircraft and automobile industries, the engineering and metal industries, the watch-making industry, paper industry, and textile industry. Typical branches in service-providing businesses include banks, insurance, consulting and computer software, trust companies and private management, and care agencies (for people and things).

An obvious approach entails a search for branch-dependent concepts. A branch model of planning and control comprises concepts appropriate to specific branches, including suitable types of business processes and business methods.

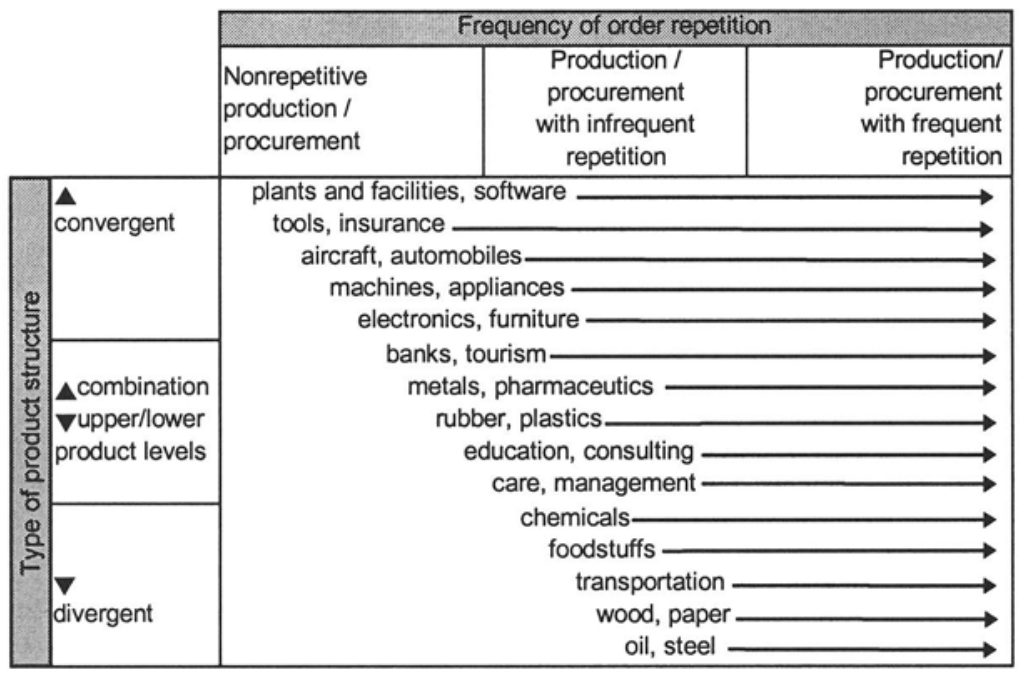

Figure 2 Two basic relations between branch and feature orientation of product structure and frequency of production or procurement order repetition.

The branch of industry or service is indeed related to many of the characteristic features of planning and control. Most branches can be assigned to a concept with the extensions as shown in Figure 1. Corresponding business methods, however, are usually too general as is to serve ideally in a particular branch. For this reason, it has been useful to go beyond those concepts and develop branch models.

Figure 2 shows two basic relations between branch and the two characteristic features already showcased in Figure 1, namely the Orientation of product structure and the Frequency of production or procurement order repetition.

The two connections are the following:

- In a first approximation, branches can be readily positioned according to the feature orientation of product structure. Thus, there is a clear relation. 
- Branches can be distinguished according frequency of order repetition relatively clearly with regard to 'one of a kind', nonrepetitive production or procurement. In all branches, however, we find varying frequencies all the way to frequent repetition. Moreover, there are exceptions in all branches, where lower repetitive frequencies can be found (f.ex., production of a chemical active substance that is produced only once for its whole life cycle). The relation here, therefore, is less clear than that to orientation of product structure.

A closer look shows that the two connections are not surprising, for here we have the same features as in Figure 1. They reflect the powerful branches for which practical concepts of planning and control in logistics were developed.

A further observation: In many cases, there is a link among the three following features shown in Figure 3 (orientation of product structure, physical organization of production infrastructure, (order) lot size):

\begin{tabular}{|c|c|c|c|c|c|c|}
\hline \multicolumn{7}{|c|}{ Features referring to user and product or product family } \\
\hline \multirow{2}{*}{$\begin{array}{l}\text { Feature } \\
\text { Orientation of } \\
\text { product } \\
\text { structure }\end{array}$} & \multirow{2}{*}{$\Rightarrow$} & \multicolumn{3}{|l|}{\begin{tabular}{|l|} 
Values \\
\end{tabular}} & & \multirow[b]{2}{*}{ divergent } \\
\hline & & \begin{tabular}{|l}
$\Delta$ \\
convergent
\end{tabular} & & & & \\
\hline \multicolumn{7}{|c|}{ Feature referring to logistics and production resources } \\
\hline Feature & \multirow[t]{2}{*}{$m$} & Values & & & & \\
\hline $\begin{array}{l}\text { Physical } \\
\text { organization of } \\
\text { the production } \\
\text { infrastructure }\end{array}$ & & site production & $\begin{array}{l}\text { production } \\
\text { islands or } \\
\text { group } \\
\text { production }\end{array}$ & $\begin{array}{l}\text { job shop } \\
\text { production }\end{array}$ & $\begin{array}{l}\text { line shop } \\
\text { production }\end{array}$ & $\begin{array}{l}\text { flow shop } \\
\text { production }\end{array}$ \\
\hline \multicolumn{7}{|c|}{ Feature referring to production or procurement order } \\
\hline Feature & \multirow[t]{2}{*}{$\rightarrow$} & \multicolumn{3}{|c|}{ Values } & & \\
\hline $\begin{array}{l}\text { (Order-) lot or } \\
\text { batch size }\end{array}$ & & $\begin{array}{l}1 \text { (single item } \\
\text { production / } \\
\text {-procurement) }\end{array}$ & $\begin{array}{l}\text { small-sized } \\
\text { (-production / } \\
\text {-procurement) }\end{array}$ & & $\begin{array}{l}\text { serial } \\
\text { (-production / } \\
\text {-procurement) }\end{array}$ & $\begin{array}{l}\text { mass } \\
\text { (-production / } \\
\text {-procurement) }\end{array}$ \\
\hline
\end{tabular}

Figure 3 Links among orientation of product structure, physical organization of the production infrastructure and (order) lot or batch size.

This link shows up when, in a first approximation, the different expressions of features in nearby columns appear together. For example:

- Convergent product structures have the tendency to appear together with site production or job shop production and together with single unit production or production and procurement with small series. This also holds in the reverse direction.

- Divergent product structures tend to appear together with flow shop production and mass or serial production and procurement. This also holds in the reverse direction.

This observation means that in Figure 2, we can replace orientation of product structure with either of the two features physical organization of production infrastructure and (order) lot or batch size. A close look reveals that, in a first approach, branches can indeed be organized according to the expressions of these two latter features as well as according to the first feature. 
It is also interesting to look at the link among features shown in Figure 4 (product concept, production concept (stocking level), frequency of order repetition):

\begin{tabular}{|c|c|c|c|c|c|c|}
\hline \multicolumn{7}{|c|}{ Features referring to user and product or product family } \\
\hline Feature & \multirow[t]{2}{*}{$\Rightarrow$} & \multicolumn{5}{|c|}{ Values } \\
\hline $\begin{array}{l}\text { Product } \\
\text { concept }\end{array}$ & & $\begin{array}{l}\text { according to } \\
\text { (changing) } \\
\text { customer } \\
\text { specification }\end{array}$ & $\begin{array}{l}\text { product family } \\
\text { with many } \\
\text { variants }\end{array}$ & product family & $\begin{array}{l}\text { Standard } \\
\text { product with } \\
\text { variants }\end{array}$ & $\begin{array}{l}\text { Individual or } \\
\text { standard } \\
\text { product }\end{array}$ \\
\hline \multicolumn{7}{|c|}{ Feature referring to logistics and production resources } \\
\hline Feature & \multicolumn{6}{|c|}{$\Rightarrow$ Values } \\
\hline $\begin{array}{l}\text { Production } \\
\text { concept } \\
\text { (stocking level) }\end{array}$ & $\rightarrow$ & $\begin{array}{l}\text { Engineer-to- } \\
\text { order (no } \\
\text { stockkeeping) }\end{array}$ & $\begin{array}{l}\text { Make-to-order } \\
\text { (design, raw } \\
\text { material) }\end{array}$ & $\begin{array}{l}\text { Assemble-to- } \\
\text { order (single } \\
\text { parts) }\end{array}$ & $\begin{array}{l}\text { Assemble-to- } \\
\text { order } \\
\text { (assemblies) }\end{array}$ & $\begin{array}{l}\text { Make-to-stock } \\
\text { (end products) }\end{array}$ \\
\hline \multicolumn{7}{|c|}{ Feature referring to production or procurement order } \\
\hline Feature & \multirow[t]{2}{*}{$\Rightarrow$} & \multicolumn{5}{|c|}{ Values } \\
\hline $\begin{array}{l}\text { Frequency of } \\
\text { order } \\
\text { repetition }\end{array}$ & & $\begin{array}{l}\text { non-repetitive } \\
\text { (-production / } \\
\text { procurement) }\end{array}$ & & $\begin{array}{l}\text { (production / } \\
\text { procurement) } \\
\text { with infrequent } \\
\text { repetition }\end{array}$ & & $\begin{array}{l}\text { (production / } \\
\text { procurement) } \\
\text { with frequent } \\
\text { repetition }\end{array}$ \\
\hline
\end{tabular}

Figure 4 Links among the features product concept, production concept and frequency of production or procurement order repetition.

In a first approximation, we find that:

- A product concept according to customer specification (f.ex. the manufacturing of plant facilities) means that part of the customer order has to run through design before procurement or production. This is exactly the meaning of engineer-to-order. Product family with many variants are generally produced using with raw materials (make-to-order). The variation of a product familiy concept with a restricted number of variants is normally obtained during assembly (assemble-to-order). Standard products are stocked on the level of end products (make-to-stock).

- Nonrepetitive production is generally typical of a product concept according to customer specification or of product families with multiple variants. Production with infrequent repetition is found with product families. Production with frequent repetition is the rule with individual or standard products and with a small number of variants.

On the basis of these observations, we can see that in Figure 2, the feature frequency of production or procurement order repetition can be replaced with either of the two features frequency of customer demand or product concept or production concept (stocking level). On close examination, it is clear that branches can indeed be arranged in a first approximation according to the expressions of the two latter features as well as according to the first feature. Just as in the case of frequency of repetition, however, there will be some exceptions. 
Varying concepts of planning and control in enterprise logistics are not in dependency upon branch of industry, i.e. the area of business a company belongs to. Each concept developed during the last decades is covering the needs of different branches. The choice of a suited concept for an enterprise is in dependency upon characteristic features of planning and control describing the consumer, the product or the product family, the logistics and production resources, the production or procurement order. The features Orientation of product structure and the Frequency of production or procurement order repetition are most important, as well as other features linked closely to those two.

Thus, in practice, it happens that several concepts of planning and control may and have to be applied in an enterprise. To be able to do this correctly and successful, a thorough analysis of the different businesses in the enterprise, seen from the logistics viewpoint, is required.

\section{REFERENCES}

Schönsleben, P. (1998) Integrales Logistikmanagment - Planung und Steuerung von umfassenden Geschäftsprozessen, Springer, Berlin, Heidelberg, NewYork

Vollmann, T.E., Berry, W.L., Whybark, D.C. (1997) Manufacturing Planning and Control Systems, 4th edition, McGraw Hill

Wight, O.W. (1981) MRPII: Unlocking Americas Productivity Potential, Oliver Wight Publications

\section{BIOGRAPHY}

Paul Schoensleben, 1952, studied Mathematics and Operation Research at the Swiss Federal Institute of Technology ETH in Zurich. He obtained a master's degree in 1977 and a Ph.D. degree in 1980. Several years of responsibilities for Computer and Organization departments of industrial companies followed. In parallel, he developed and introduced a PPC package, today called Expert/400. From 1983 to 1991 he has been ordinary professor for Business Informatics at the University of Neuchatel, Switzerland. Since 1991 he is ordinary professor for Industrial Engineering and Management at the Swiss Federal Institute of Technology ETH in Zurich, Switzerland. 